\title{
Correction to: The Schläfli Fan
}

\author{
Michael Joswig $^{1,2}$ (D) Marta Panizzut ${ }^{1}$ (D) $\cdot$ Bernd Sturmfels $^{2,3}$
}

Published online: 9 August 2021

(c) The Author(s) 2021

\section{Correction to: Discrete \& Computational Geometry (2020) 64:355-381 https://doi.org/10.1007/s00454-020-00215-x}

The article "The Schläfli Fan", written by Michael Joswig, Marta Panizzut, and Bernd Sturmfels, was originally published electronically on SpringerLink on 20 June 2020 without Open Access. With the author(s)' decision to opt for Open Choice the copyright of the article changed 16 July 2021 to The Author(s) 2020 and the article is forthwith distributed under the terms of the Creative Commons Attribution.

\begin{abstract}
Open Access This article is licensed under a Creative Commons Attribution 4.0 International License, which permits use, sharing, adaptation, distribution and reproduction in any medium or format, as long as you give appropriate credit to the original author(s) and the source, provide a link to the Creative Commons licence, and indicate if changes were made. The images or other third party material in this article are included in the article's Creative Commons licence, unless indicated otherwise in a credit line to the material. If material is not included in the article's Creative Commons licence and your intended use is not permitted by statutory regulation or exceeds the permitted use, you will need to obtain permission directly from the copyright holder. To view a copy of this licence, visit http://creativecommons.org/licenses/ by $/ 4.0 /$.
\end{abstract}

Publisher's Note Springer Nature remains neutral with regard to jurisdictional claims in published maps and institutional affiliations.

The original article can be found online at https://doi.org/10.1007/s00454-020-00215-x.

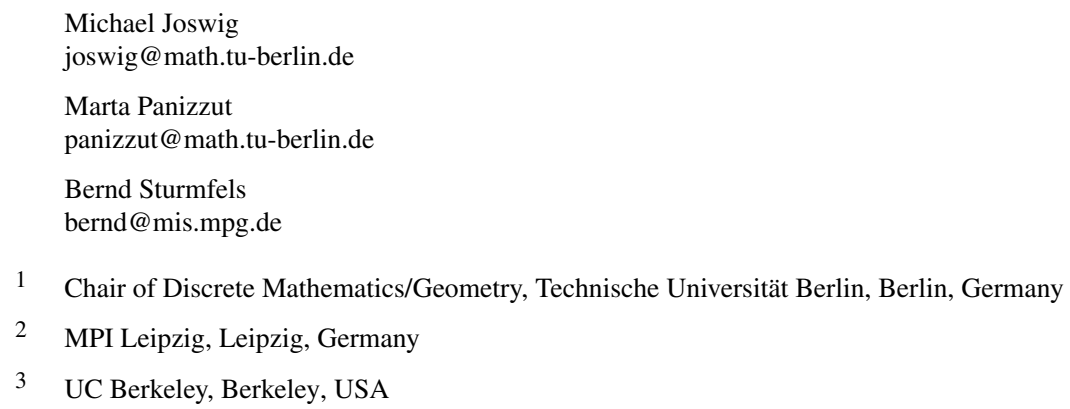

